\title{
Geological development of the Limpopo Shelf (southern Mozambique) during the last sealevel cycle
}

\author{
Stefan Wenau ${ }^{1,2} \cdot$ Benedict Preu $^{1,2} \cdot$ Volkhard Spiess $^{1}$ \\ Received: 16 October 2019 / Accepted: 5 March 2020 / Published online: 26 March 2020 \\ (C) The Author(s) 2020
}

\begin{abstract}
Paleo-shorelines on continental shelves give insights into the complex development of coastlines during sealevel cycles. This study investigates the geologic development of the Limpopo Shelf during the last sealevel cycle using multichannel seismic and acoustic datasets acquired on the shelf in front of the Limpopo River mouth. A detailed investigation of seismic facies, shelf bathymetry, and a correlation to sea level revealed the presence of numerous submerged shorelines on the shelf. These shorelines are characterized by distinct topographic ridges and are interpreted as coastal dune ridges that formed in periods of intermittent sealevel still-/slowstand during transgression. The shorelines are preserved due to periods of rapid sealevel rise (melt water pulses) that led to the overstepping of the dune ridges as well as due to early cementation of accumulated sediments that increased the erosive resistance of the ridges. The high along-shelf variability of the submerged dune ridges is interpreted as a result of preexisting topography affecting shoreline positions during transgression. The pre-existing topography is controlled by the underlying sedimentary deposits that are linked to varying fluvial sediment input at different points on the shelf. The numerous prominent submerged dune ridges form barriers for the modern fluvial sediment from the Limpopo River and dam sediment on the inner shelf. They may also facilitate along-shelf current-induced sediment transport.
\end{abstract}

\section{Introduction}

The shape of continental shelves worldwide is strongly influenced by sediment deposition and erosion as well as shoreline development in response to numerous sealevel cycles in the Pleistocene. Ancient shorelines on the shelf that have been drowned during transgressive stages may form distinctive remnants that are potentially buried by subsequent sedimentation (e.g., Locker et al. 1996; Gardner et al. 2005, 2007; Nichol and Brooke 2011; Brooke et al. 2014; Green et al. 2014). These shorelines allow insights into coastline behavior in times of rising sea level. Their development depends on various factors such as pre-existing topography, available sediment, and the global dynamics of sealevel rise (Cooper and Pilkey 2004; Pretorius et al.

Stefan Wenau

swenau@uni-bremen.de

1 Department of Geosciences, University of Bremen, Klagenfurter Str. 2-4, Bremen 28359, Germany

2 Present address: Fraunhofer IWES, Fraunhofer Institute for Wind Energy Systems, Am Fallturm 5, Bremen 28359, Deutschland
2016; Green et al. 2018). Paleo-shorelines on the shelf are preserved due to an overstepping during periods of rapid sealevel rise (Kelley et al. 2010; Zecchin et al. 2011; Mellett et al. 2012; Green et al. 2013). Additionally, they often show a high resistance to erosion due to early cementation, coarse sediment grain sizes, and the geometry of the surrounding shelf (Storms et al. 2008; Mellett et al. 2012; Green et al. 2013, 2018).

In this study, we reconstruct the geological development of the shelf in front of the Limpopo River mouth during the last sealevel cycle. Multichannel seismic and acoustic data are presented that allow a detailed mapping of seismic units in the sub-seafloor. Additionally, bathymetric data reveal coastparallel topographic ridges on the shelf. These ridges are presumably formed as coastal dunes during periods of sealevel slow-/stillstand during the transgression after the Last Glacial Maximum (LGM) and show a high lateral variability over short distances. This variability in shelf topography is attributed to differences in outer shelf sediment accumulation/ erosion and pre-existing topography on the shelf that affect coastline development during sealevel rise. This study for the first time explores the geological development of the southern Mozambique shelf area and extends previous work on shelf evolution on the southeastern African margin. 


\section{Regional setting}

The Delagoa Bight is a large ocean embayment created by the westward offset of the southern Mozambique coastline (Fig. 1). It is characterized by a narrow Limpopo Shelf area of $15-35 \mathrm{~km}$ in its western and northern part with a shelf break at $\sim 120 \mathrm{~m}$ (Figs. 1 and 2). The extensive Inharrime Shelf to the east transitions into a large contourite deposit on the upper slope of the Inharrime Terrace (Fig. 1) (Preu et al. 2011). The region is dominated oceanographically by the Agulhas Current (AC), which is formed by the Mozambique Current (MC) and the East Madagascar Current (EMC) (Fig. 1) (Martin 1981; Lutjeharms 2006). The topographically trapped cyclonic lee eddy in the Delagoa Bight (Fig. 1) (Saetre and Da Silva 1984; Lamont et al. 2010) resembles similar settings along the southeastern African margin (Flemming 1981; Lutjeharms and Da Silva 1988). The northern coast of the Delagoa Bight is formed by the Mozambique coastal plain, which is characterized by Neogene coast-parallel linear dune ridges, separated by swamp areas or shallow flat basins (Tinley 1985; Hughes and Hughes 1992; Botha et al. 2003; Armitage et al. 2006; Porat and Botha 2008). Active coastal dune systems at the shoreline reach heights of $>100 \mathrm{~m}$ due to the stacking of dune generations during successive sealevel highstands (Cooper and Pilkey 2002; Sudan et al. 2004; Armitage et al. 2006). The main source of sediment input to the Delagoa Bight is the Limpopo River that drains $370,000 \mathrm{~km}^{2}$ of hinterland (Flemming 1981). Estimates of the sedimentary load vary between $33 \times 10^{6}$ (Flemming 1981) and $48.8 \times 10^{6}$ t/year (Milliman and Meade 1983), being comparable to sediment loads of the Niger and Congo Rivers with $40 \times 10^{6}$ and $43 \times 10^{6}$ t/year, respectively (Milliman and Meade 1983). Limpopo River sediment is thought to form the Limpopo Cone (Martin 1981); however, a large fraction of the sediment is being dispersed in the ocean (Walsh and Nittrouer 2009). Recently, it has been shown that a large part of Limpopo sediment is transported eastwards on the shelf, attributed to the Delagoa Bight eddy (Schüürman et al. 2019).

The southern Mozambique continental shelf has not been a focus of geoscientific research in the last decades, with the exception of studies on coastal development south of Maputo (Cooper and Pilkey 2002; Armitage et al. 2006; Green et al. 2015) and sediment provenance in the Delagoa Bight (Schüürman et al. 2019). However, the neighboring KwaZulu-Natal shelf in South Africa has been investigated by a number of studies. These focus mainly on the effects of shoreline variations on shelf deposits during the last sealevel cycle and sediment dynamic processes on the shelf(Flemming 1980, 1981; Ramsay 1994; Green and Uken 2005; Green et al. 2008; Green 2009; Green and Luke Garlick 2011; Green et al. 2013, 2014, 2018; Salzmann et al. 2013; Cooper et al. 2016; Pretorius et al. 2016, 2018). These studies reveal widespread paleo-coastlines on the shelf including beachrock and aeolianite ridges on the seafloor. These ridges were formed during the post-glacial transgression in the course of sealevel stillstands and preserved due to overstepping during periods of rapid sealevel rise (Salzmann et al. 2013; Green et al. 2014; Pretorius et al. 2016).

\section{Methods}

The multichannel seismic data presented in this study were acquired during $R / V$ Meteor Cruise M75/3 in 2008 with the University of Bremen high-resolution multichannel seismic equipment (Fig. 1). A Sercel GI-Gun with a volume of $2 \times$ 0.1251 was used as a source, yielding a frequency range of $100-600 \mathrm{~Hz}$ with a central frequency of $\sim 200 \mathrm{~Hz}$. Data was recorded with a 50-m-long streamer containing 48 single hydrophones with a $1 \mathrm{~m}$ channel spacing. The data were processed applying standard techniques including common midpoint sorting (distance $1 \mathrm{~m}$ ), band pass filtering, stacking, and post-stack time migration. Vertical data resolution resulting from the source frequency is between 2 and $4 \mathrm{~m}$. Data processing was carried out with the Schlumberger Vista seismic processing software package. For data interpretation, the IHS Kingdom software package was used. Time depth conversions were done using a seismic velocity of $1500 \mathrm{~ms}^{-1}$, which is a suitable velocity for the shallow sub-seafloor.

Additionally, $4 \mathrm{kHz}$ parametric sediment echosounder data were recorded in parallel to the multichannel seismic data acquisition using the hull-mounted Parasound system. This data was used to image the shallowest sediment deposits to a depth of $\sim 20 \mathrm{~m}$ at a decimeter-scale resolution. Furthermore, bathymetric data was acquired with the hull-mounted Kongsberg EM710 multibeam echosounder (Fig. 2). The data were cleaned and gridded with a grid cell size of $10 \times 10 \mathrm{~m}$.

\section{Results}

\section{Bathymetry of the Limpopo shelf}

The Limpopo Shelf is $\sim 20 \mathrm{~km}$ wide (Fig. 1) and its surface is characterized by a large number of coast-parallel ridges (Fig. 2). These ridges were observed in water depths between $\sim 40$ and $100 \mathrm{~m}$. They show a maximum height of $20 \mathrm{~m}$ and a width of between 100 and $700 \mathrm{~m}$ (Fig. 2). Their shape is variable with some showing flat tops and an extended width while others appear narrow with rounded tops. The ridges occur individually or in sets of several individual ridges that are located in close proximity to each other and sometimes overlap (Fig. 2B). The lateral continuity of ridges is highly variable making correlation of ridges between bathymetric profiles difficult (Fig. 2). Sets of ridges show a high degree of variability with individual ridges 


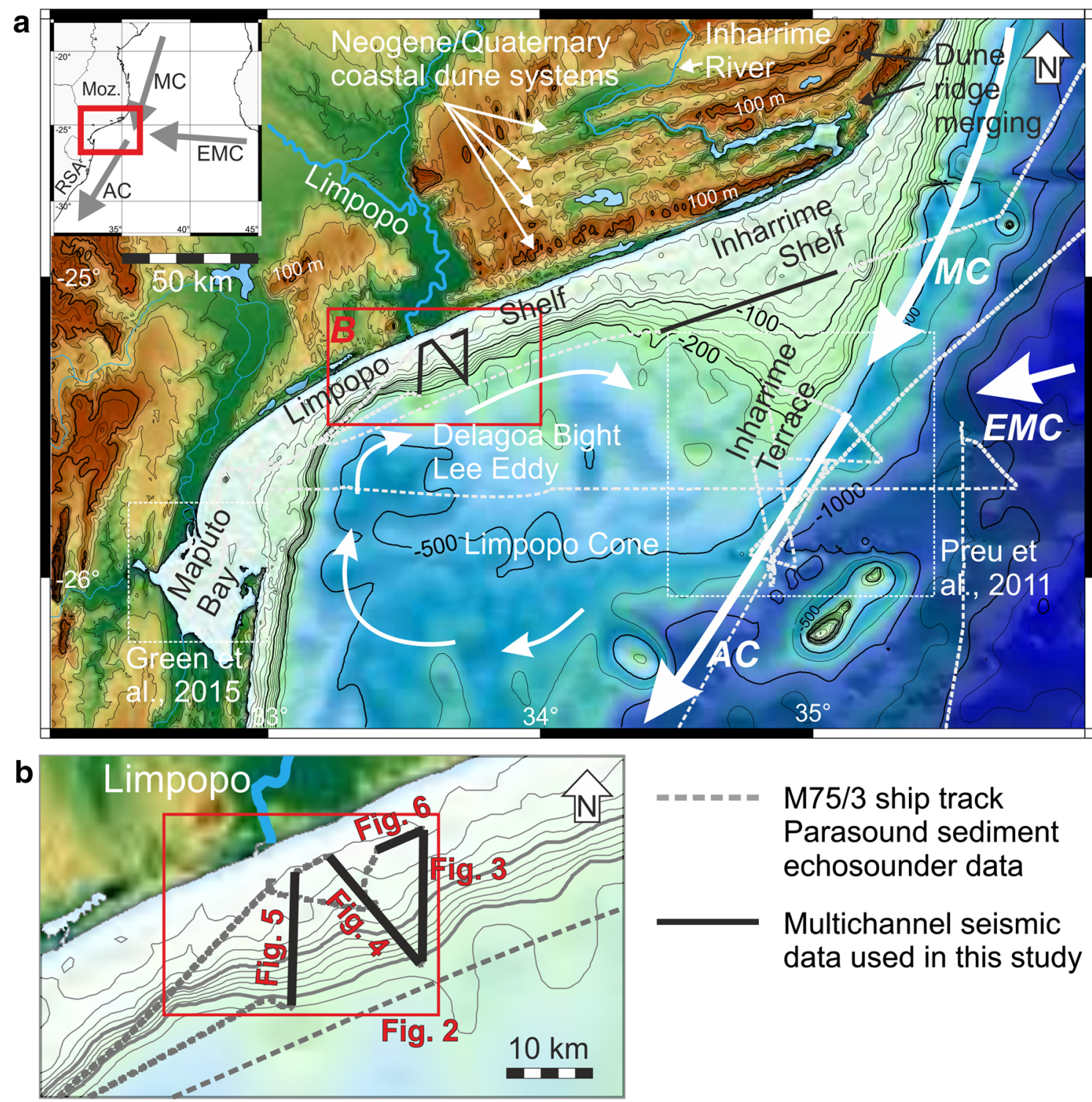

Fig. 1 (A) Topographic map of the Delagoa Bight and the southern Mozambique continental margin. White arrows show the current system, dominated by the Mozambique Current (MC), the east Madagascar Current (EMC), and the resulting Agulhas Current (AC). A stationary lee circulation in the Delagoa Bight is induced by this setting.

terminating, splitting or merging within few hundred meters distance (Fig. 2B). In front of the Limpopo River mouth, the character of these topographic ridges changes from numerous prominent ridges in the west to sets of individual ridges that appear partly buried by sediment in the east (Fig. 2C). The outer shelf is $\sim 3 \mathrm{~km}$ wider and relatively flat in the east compared to its narrow width in the west with topographic ridges close to the shelf break (Fig. 2C). The position of individual ridgelines on the shelf differs between profiles (Fig. 2). Three ridgelines can be observed on the eastern bathymetric profiles at $\sim-95 \mathrm{~m}, \sim-65 \mathrm{~m}$, and $\sim$ $40 \mathrm{~m}$ water depth (Fig. 2). They can tentatively be correlated to ridges on the western profiles (Fig. 2C) although these show significantly more ridges with a more diverse morphology.
Large quantities of sediment are introduced to the shelf via the Limpopo River. The southern Mozambique coastal plain is dominated by coastparallel Neogene dune systems. (B) Detailed map of the Limpopo Shelf showing the multichannel seismic profiles presented in this study

\section{Seismic units}

The seismic data, as presented in Figs. 3, 4, 5, and 6, reveals a complex shelf stratigraphy to depths of greater than $250 \mathrm{~m}$. However, in this study, we focus on the upper $\sim 50 \mathrm{~m}$ of the seismic profiles and examine five seismic units (SU 1 to SU 5, Table 1) above the first observed major unconformity (MIS-6 unconformity).

\section{Seismic unit 1}

Seismic Unit 1 (SU 1) lies on the outer shelf and shelf edge (Figs. 3,4 , and 5). It shows a thickness of up to $100 \mathrm{~m}$ and comprises 


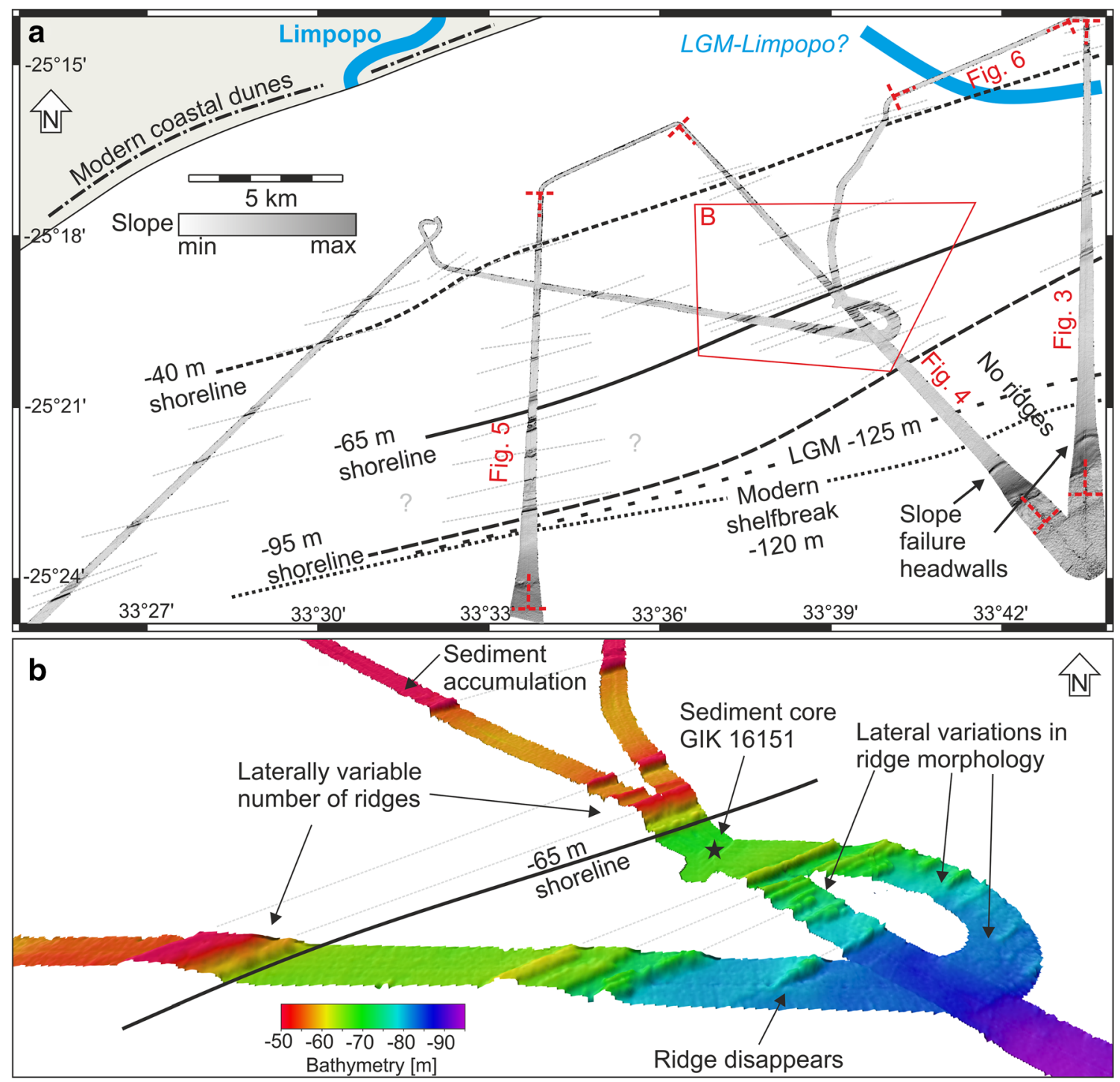

C

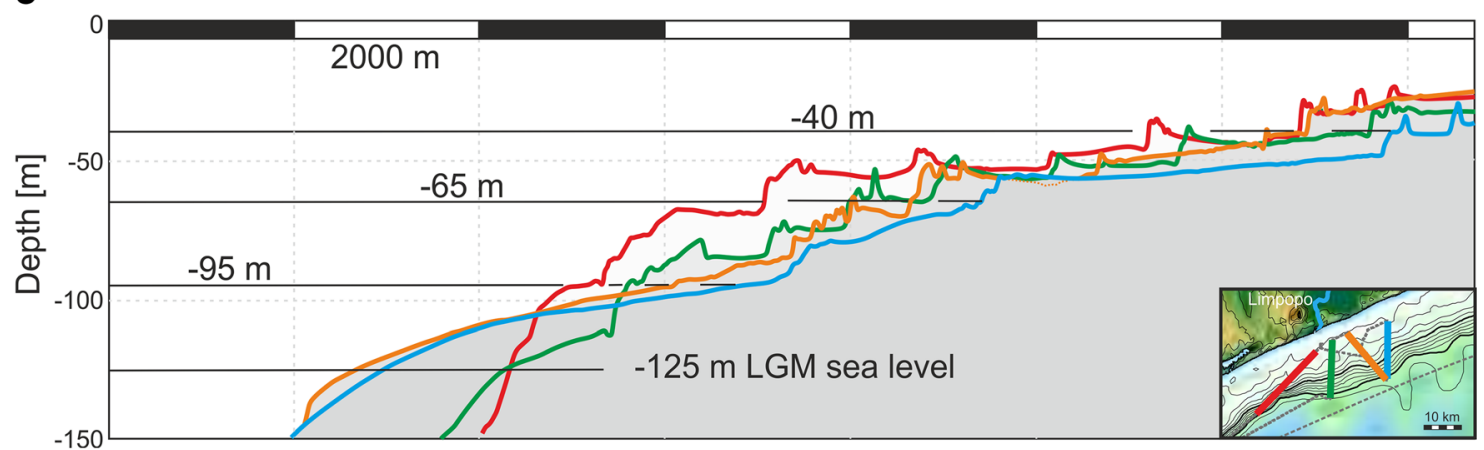

Fig. 2 (A) Seafloor bathymetry slope of the Limpopo Shelf from multibeam echosounder data. For location see Fig. 1. Submerged dune ridges were mapped and extrapolated from their strike in the bathymetric data (gray stippled lines). They are oriented coast-parallel and show heights of up to $20 \mathrm{~m}$. The ridges show a high variability in continuity and geometry over distances of few kilometers along the shelf. Three distinct ridgelines could be correlated at $-95,-65$, and $-40-\mathrm{m}$ water depth. (B) Perspective view of dune ridges on the middle shelf showing small-scale variability of individual ridges, such as merging and splitting of ridges. (C) Bathymetric profiles extracted from multibeam echosounder data along four profiles on the Limpopo Shelf (see inset). Profiles were projected to an across-shelf transect orientation, allowing spatial comparison. All profiles are anchored at a similar distance from the coast at their landward end. An increase in shelf width and ridge burial as well as a low-relief outer shelf is visible towards the east 

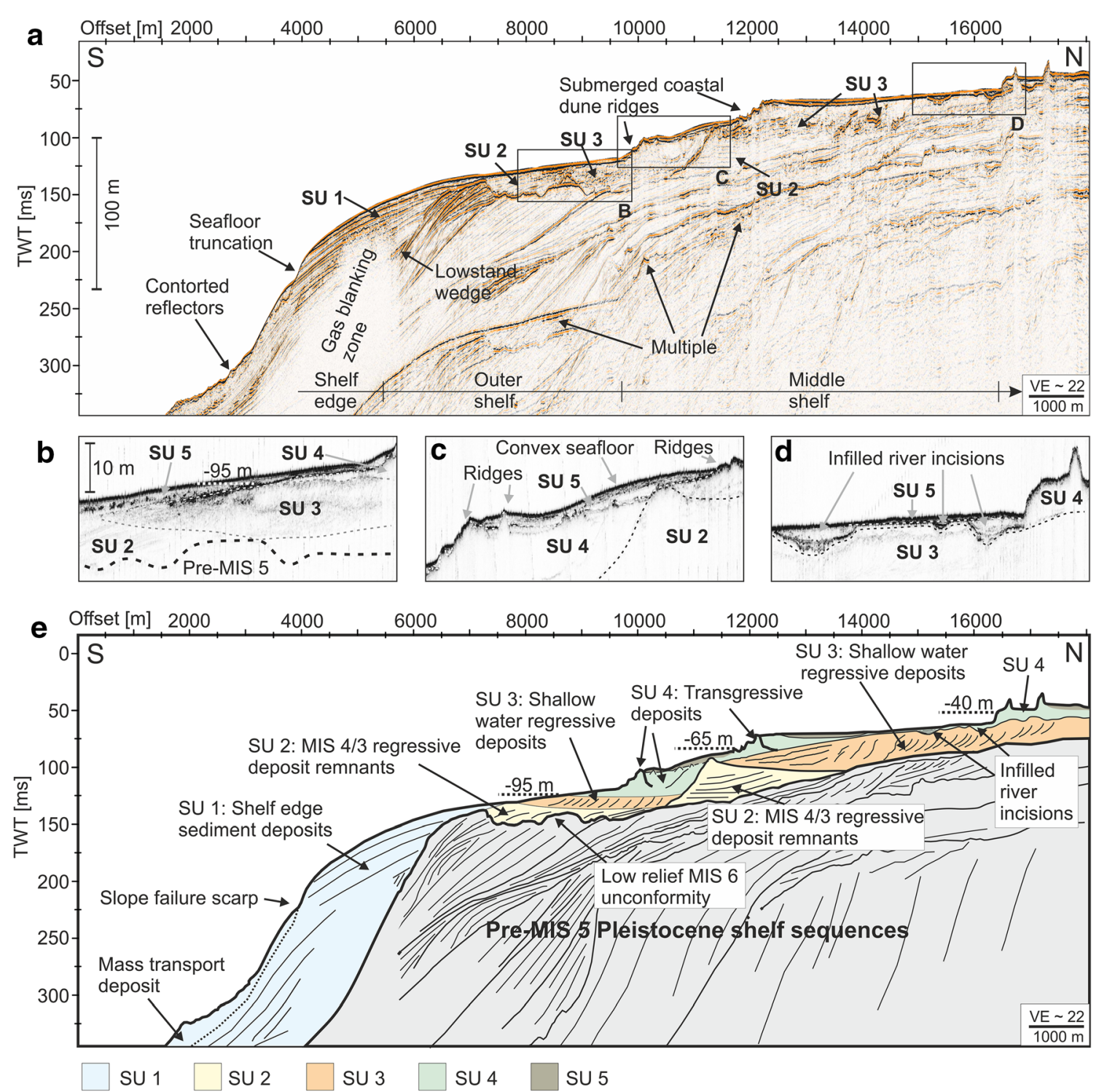

Fig. 3 (A) Multichannel seismic profile GeoB08-183, for location see Figs. 1 and 2. Dominant features are partly buried submerged coastal dune ridges. The sedimentary shelf sequence is dominated by truncation surfaces and shelf-edge sediment accumulations, corresponding to sealevel cycles. (B-D) Close-ups of Parasound echosounder data (see A for position) showing details of identified seismic units. (E) Interpretative line drawing of A showing seismic units associated with the most recent sea-level cycle. See text for detailed description and interpretation. $\mathrm{SU}=$ Seismic Unit

blanking presumably induced by gas in the sediments can be observed in the thick eastern parts of SU 1 (Figs. 3 and 4).

\section{Seismic Unit 2}

Seismic Unit 2 (SU 2) occurs in the eastern part of the study area where it is preserved extensively on the middle shelf and otherwise limited to small patches within topographic depressions in the MI6 unconformity on the outer shelf(Figs. 3 and 4). It shows thicknesses of up to $15 \mathrm{~m}$ and consists of low to medium amplitude parallel to subparallel reflectors. SU 2 reflectors downlap seawards onto the MIS-6 unconformity (Fig. contorted reflectors further seaward (Fig. 3A). Amplitude 

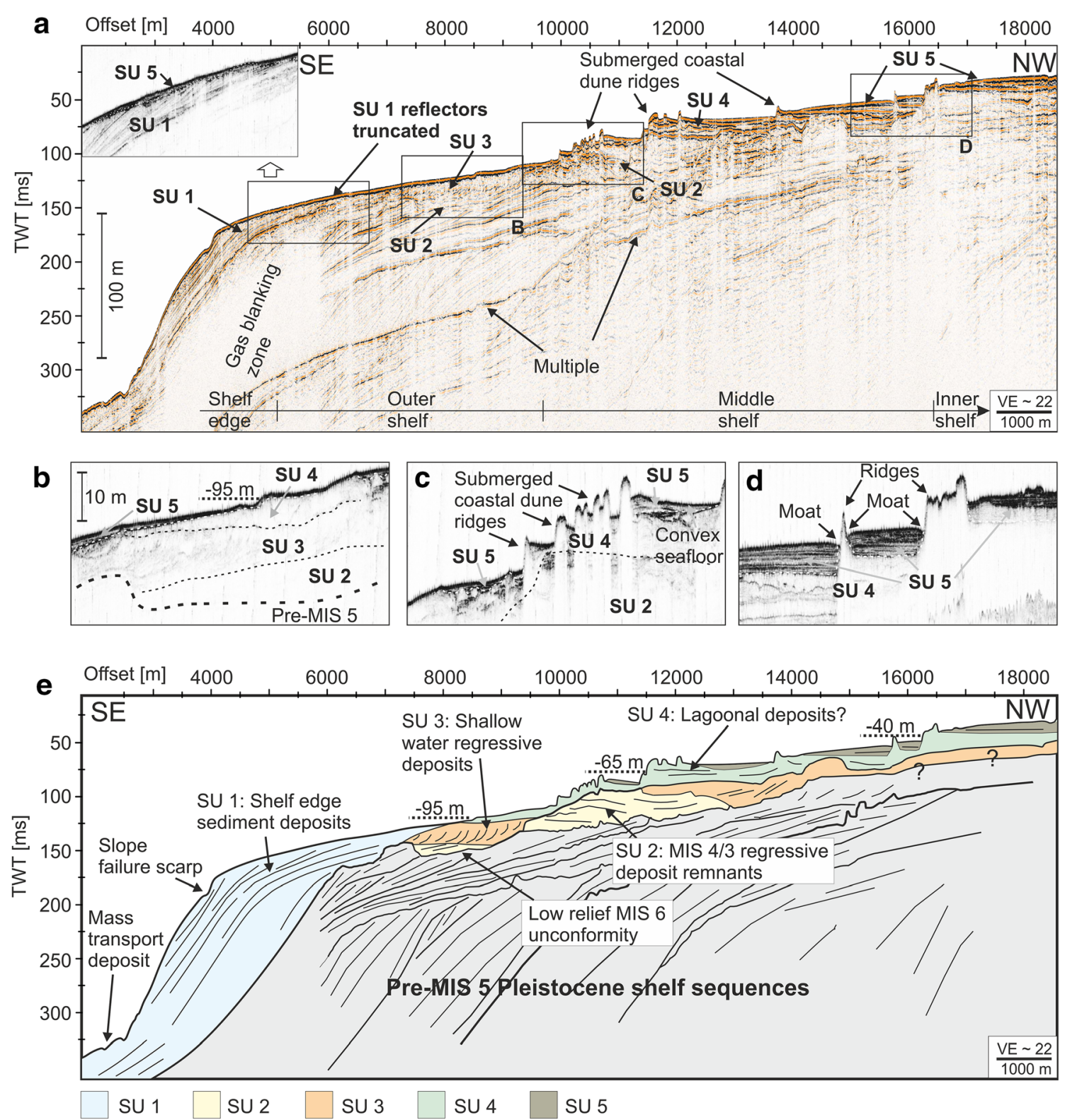

Fig. 4 (A) Multichannel seismic profile GeoB08-182, for location see Figs. 1 and 2. Dominant features are partly buried submerged coastal dune ridges. The sedimentary shelf sequence is dominated by truncation surfaces and shelf-edge sediment accumulations, corresponding to sealevel cycles. (B-D) Close-ups of Parasound echosounder data (see A for

$3 \mathrm{~A}$ and B). Landwards it onlaps or lies conformably on the MIS-6 unconformity (Figs. 3 and 4). SU 2 is truncated and overlain by SU 3-5 (Figs. 3C and 4C). The geometry of SU 2 appears to dictate the severity of the truncation, which appears most intense on the seaward side of the SU 2 middle shelf occurrence.

\section{Seismic Unit 3}

Seismic Unit 3 (SU 3) is present on the inner and middle shelf and shows a thickness of 10-20 m. While SU 3 can be position) showing details of identified seismic units. (E) Interpretative line drawing of A showing seismic units associated with the most recent sea-level cycle. See text for detailed description and interpretation. SU = Seismic Unit

observed over the whole shelf width in the western part of the study area (Fig. 5), it is not present in the eastern part on the middle shelf where SU 2 deposits are present (Figs. 3 and 4). It consists of steeply seaward dipping $\left(5^{\circ}-10^{\circ}\right)$ reflector packages of medium to high amplitude (Figs. 3, 4, and 5). The reflector dip angles decrease towards the base of the unit (Fig. 5). SU 3 reflectors downlap onto the underlying major (MIS 6) unconformity, especially in the northern parts of the profiles (Figs. 3 and 5). Further seaward, SU 3 truncates SU 2 reflectors (Fig. 3B and 4B). SU 3 is overlain by SU 5 at its most seaward occurrence on the middle shelf (Figs. 3B and 4B) and 

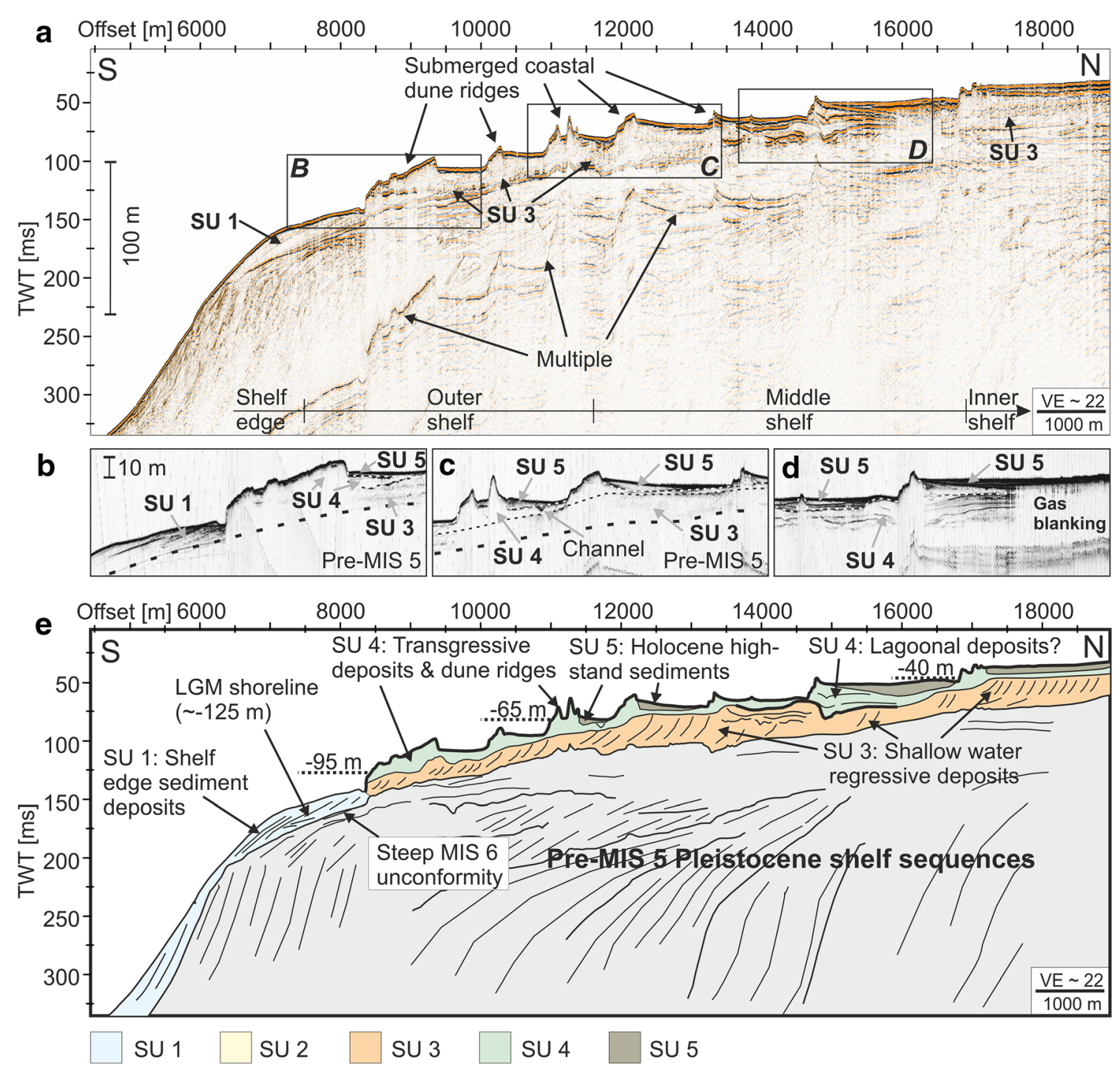

Fig. 5 (A) Multichannel seismic profile GeoB08-180, for location see Figs. 1 and 2. Submerged coastal dune ridges show a prominent topography. The sedimentary shelf sequence is dominated by truncation surfaces and shelf-edge sediment accumulations, corresponding to sealevel cycles. SU 2 is not present in this western part of the Limpopo Shelf. Note the relative small thickness of SU 1 on the outer shelf compared to

Figs. 3 and 4. (B-D) Close-ups of Parasound echosounder data (see A for position) showing details of identified seismic units. (E) Interpretative line drawing of A showing seismic units associated with the most recent sea-level cycle. See text for detailed description and interpretation. $\mathrm{SU}=$ Seismic Unit

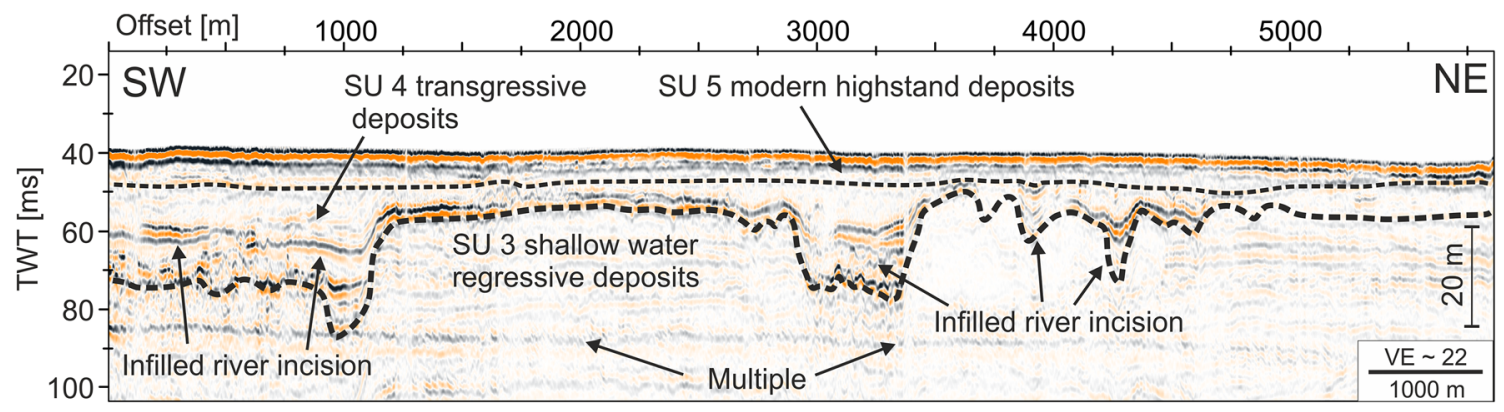

Fig. 6 Multichannel seismic profile GeoB08-184, for location see Figs. 1 and 2. Shallow regressive sediments (SU 3 ) are truncated by the overlying sub-aerially exposed surface during MIS 2-3 sealevel lowstand. Significant incisions are attributed to fluvial activity, possibly the Paleo-
Limpopo. The incisions are subsequently filled during the transgression by SU 4 deposits. See text for detailed description and interpretation. SU $=$ Seismic Unit 
Table 1 Overview of identified seismic units on the continental shelf

\begin{tabular}{|c|c|c|c|c|}
\hline $\begin{array}{l}\text { Seismic } \\
\text { unit }\end{array}$ & $\begin{array}{l}\text { Location on } \\
\text { continental shelf }\end{array}$ & Thickness [m] & Internal seismic character & Unit boundaries \\
\hline SU 1 & $\begin{array}{l}\text { Outer and shelf } \\
\text { edge }\end{array}$ & Up to 100 & $\begin{array}{l}\text { Parallel southward-dipping reflections, medium ampli- } \\
\text { tude }\end{array}$ & $\begin{array}{l}\text { Onlaps on MIS } 6 \text { unconformity below, upper } \\
\text { part partly truncated }\end{array}$ \\
\hline SU 2 & Middle to outer & Up to 15 & $\begin{array}{l}\text { Parallel medium amplitude reflections, horizontal to } \\
\text { southward-dipping geometry }\end{array}$ & $\begin{array}{l}\text { Downlap and onlap on MIS } 6 \text { unconformity, } \\
\text { upper part truncated }\end{array}$ \\
\hline SU 3 & Inner to middle & $10-20$ & $\begin{array}{l}\text { Steeply southward-dipping reflections, medium to high } \\
\text { amplitude }\end{array}$ & $\begin{array}{l}\text { Downlap on MIS } 6 \text { unconformity and SU 2, } \\
\text { upper part truncated }\end{array}$ \\
\hline SU 4 & Complete & $1-20$ & Acoustically transparent & $\begin{array}{l}\text { Conformable lower boundary, partly } \\
\text { truncated upper boundary }\end{array}$ \\
\hline SU 5 & Complete & $1-5$ & $\begin{array}{l}\text { Acoustically transparent on outer shelf to high } \\
\text { amplitude on inner shelf }\end{array}$ & Unit drapes underlying units \\
\hline
\end{tabular}

by SU 4 further northwards (Figs. 3B, D and 4B, C). The upper boundary of SU 3 shows shallow incisions of few meters depth and several hundred meters width on the middle to inner shelf (Fig. 3A and D). These incisions can also be seen on a coast-parallel profile (Fig. 6).

\section{Seismic Unit 4}

Seismic Unit 4 (SU 4) is very variable in its appearance and thickness. It occurs from the outer shelf to the inner shelf and shows thicknesses of 1-20 m. The thickness varies significantly as the unit comprises thin draping deposits as well as the prominent topographic ridges on the shelf (Fig. 3D). The unit appears acoustically transparent in large parts and infills the incisions that have been observed in the upper part of SU 3 (Fig. 3D). The topographic ridges likewise show a transparent interior and a high amplitude upper boundary. SU 4 generally shows an upper boundary that is characterized by high amplitude peak-like events which are partly buried either by SU 4 or SU 5 deposits (Figs. 3C and 4B). SU 4 also contains parallel to subparallel medium amplitude reflectors in some parts of the middle shelf (Figs. 4D and 5D). The unit is generally overlain by SU 5 (Figs. 3, 4, and 5) and the rounded to flat tops of the ridges suggest some degree of truncation of SU 4.

\section{Seismic Unit 5}

Seismic Unit 5 (SU 5) occurs uppermost in the seismic and acoustic data. It is a thin draping unit that is present on the whole shelf. The thickness of this unit varies between $<1 \mathrm{~m}$ on parts of the outer shelf (Fig. 4B) and several meters on the inner shelf (Fig. 4D). SU 5 is beyond the resolution capabilities of the multichannel seismic data; however, the echosounder data shows it to be an acoustically transparent unit for the majority of the shelf (Fig. 3B-D). A notable exception is on the inner shelf landward of prominent ridges where it is characterized by high amplitude horizontal parallel reflectors (Figs. 4D and 5D). SU 5 shows a convex shape at the seafloor on the middle shelf (Fig. 3C and 4C) and moats run along topographic ridges (Fig. 4D). Locally, the acoustic signal is attenuated beneath high amplitude reflectors of this unit. (Fig. 5D).

\section{Discussion}

\section{Seismic stratigraphy}

The observed seismic units have all been deposited during different periods of sealevel development, as interpreted from their appearance in the seismic and acoustic data. All interpreted seismic units occur above a major unconformity that is present on the whole continental shelf. Due to the nature of the encountered seismic units above and the implied sealevel development, this unconformity has been attributed to the MIS 6 sealevel lowstand, which has not been imaged and interpreted in the region previously.

SU 1 on the outer shelf and the shelf edge is interpreted as a shelf-edge sediment wedge, due to its medium amplitude parallel reflections (Figs. 3 and 4) that suggest relatively lowenergy sediment accumulation. The thickness of the unit, especially in the eastern profiles (Figs. 3 and 4) indicates considerable sediment input to the outer shelf. Slope failures at the upper slope and associated mass transport deposits are apparent as convolute and contorted reflectors (Figs. 3 and 4). Sea level appears to have been at least $\sim 100 \mathrm{~m}$ or higher during SU 1 deposition, based on the landward limit of the unit. Furthermore, a lower sea level would have resulted in a higher energy environment at the outer shelf and the shelf edge, resulting in more disturbed reflection patterns. The unit does not appear to be active during high sea level as it is restricted to the outer shelf and shelf edge (Figs. 3, 4, and 5), where it is overlain by SU 5 (Fig. 4A). Thus, SU 1 formation is attributed to a time of lowered sea level but not LGM sea level. SU 2, with its medium amplitude parallel reflectors that indicate a relatively low-energy environment and that downlap onto a 
previously truncated surface, is interpreted as a regressive deposit (e.g., Hübscher and Spiess 2005). It is present on the middle shelf where sedimentary deposits of up to $15 \mathrm{~m}$ thickness formed (Figs. 3 and 4). This sediment accumulation presumably formed during falling sea level at medium water depths, which corresponds to the medium amplitude parallel reflectors which indicate a relatively low-energy environment. Overlying SU 1 and 2, the packages of steep seaward dipping reflectors of SU 3 show a high amplitude that indicates a highenergy depositional environment and are interpreted as shallow water regressive deposits. Based on the reflection geometry, SU 3 may be interpreted as a shore face setting (e.g., Novak and Pedersen 2000), where the steeper upper part and the flatter lower part of SU 3 reflections may represent the upper and lower shore face, respectively. These could only be formed and preserved during regression, which is also consistent with the truncation of SU 2 by this unit (Figs. 3 and 4), indicating the erosion of deposits formed in medium water depth on the shelf during continued sealevel fall (Figs. 3B and 4B). The shallow incisions visible in the top of SU 3 (Figs. 3D and 6) resemble fluvial valleys (e.g., Nordfjord et al. 2006; Darmadi et al. 2007) and suggest a subaerial exposure of the surface, supporting the interpretation of SU 3 as a regressive unit. The overlying SU 4 shows high amplitude surfaces and transparent unit interiors, suggesting coarse sediments and/or hard surfaces. This suggests a high-energy environment for the formation of the unit as can be expected for a transgressive phase. The prominent topographic ridges of SU 4 resemble lithified coastal dune ridges that formed during sealevel slow-/stillstands on the shelf (Salzmann et al. 2013; Green et al. 2014; Pretorius et al. 2016). SU 4 also fills the fluvial incisions in SU 3 (Fig. 3C and 6), indicating a flooding of the former land surface (Fig. 3D). SU 4 thus represents a generally thin transgressive deposit with numerous submerged coastal dune ridges which show heights of up to $20 \mathrm{~m}$. The base of these dune ridges corresponds generally to the sea level during their formation, which is used for a sealevel reconstruction ("Post-LGM sealevel rise" section). The thickness of SU 5 is comparably small (Fig. 3B-D), except behind dune ridges on the middle to inner shelf where material is apparently dammed (Fig. 4D). The unit is interpreted as highstand sediments formed by the modern sedimentation on the Limpopo Shelf, supported by its presence as the uppermost sedimentary deposit in most locations of the shelf (e.g., Green et al. 2013). The high amplitudes of landward SU 5 reflectors (Fig. 4D) may represent coarse sediments from the Limpopo River that accumulate behind submerged coastal dune ridges, similar to examples from the South African continental shelf (Flemming 1981).

These interpreted seismic units suggest that SU 1-5 represent a full sealevel cycle from regressive shelf deposits (SU 2), regressive shore face sediments (SU 3) to transgressive (SU 4) and modern highstand sediments (SU 5). Thus, the major unconformity underlying all described seismic units corresponds to the sub-aerially exposed shelf surface of the penultimate glacial sealevel lowstand (MIS 6). The erosive surface associated with the LGM sealevel lowstand (MIS 2) is less apparent between SU 2/3 and 4. This may be due to the relatively short duration of maximum sealevel lowstand during the LGM (Ramsay and Cooper 2002).

\section{Late Pleistocene evolution of the South Mozambique continental margin}

\section{Pre-LGM sealevel fall}

Based on the interpretation of seismic units and their geometric relationship, the development of the Limpopo Shelf in the Late Pleistocene has been reconstructed (Fig. 7). As mentioned above, the uppermost major erosive unconformity has been attributed to the MIS 6 (191-130 ka, Lisiecki and Raymo 2005) lowstand surface during the penultimate glaciation when the complete shelf had been sub-aerially exposed (Waelbroeck et al. 2002). This unconformity is directly overlain by regressive deposits of SU 2 on the middle and parts of the outer shelf (Figs. 3E and 4E), which are interpreted as having formed during the sealevel fall of MIS 4 and 3 (MIS 4: 71-57 ka; MIS 3: 57-29 ka; Lisiecki and Raymo 2005) (Fig. 7B). Transgressive and highstand deposits between the MIS 6 unconformity and SU 2 could not be identified, possibly due to the thin nature of such deposits and limited resolution and signal penetration of the seismic and acoustic data, respectively. The regressive deposits (SU 2) are generally eroded and only preserved in some locations on the middle and outer shelf where they are directly overlain by SU 3 (Fig. $3 \mathrm{~A}, \mathrm{~B}$, and $\mathrm{E})$. The shallow water regressive deposits of SU 3 are thus younger and were presumably also formed during the regression of MIS 4-2 landward of SU 2 deposits (MIS 4: 71$57 \mathrm{ka}$; MIS 3: 57-29 ka; MIS 2: 29-14 ka; Lisiecki and Raymo 2005) (Fig. 7B). During the regression, most deposits of SU 2 were eroded as they came into the high-energy shallow water zone and SU 3 often overlies directly the MIS 6 unconformity (Figs. 3, 4, 5, and 7A, B).

The preservation of SU 2 strata on the middle shelf may be due to a period of relatively stable sea level at $\sim-50 \mathrm{~m}$ during MIS 3 before continued rapid sealevel fall towards MIS 2 (Ramsay and Cooper 2002). A relatively stable sea level for an extended time period during MIS 3 at $\sim 50 \mathrm{~m}$ resulted in a truncation of the upper boundary of SU 2 but allowed the preservation of SU 2 strata below the wave base. The rapid sealevel fall from -50 to $-90 \mathrm{~m}$ at the onset of MIS 2 (Ramsay and Cooper 2002) allowed SU 2 deposits to remain in place on the middle shelf (Fig. 7B and C). The following drop of the sea level to the LGM minimum (Fig. 7D) was relatively short and did not allow sufficient time for more extensive subaerial truncation of the SU 2 deposits. 

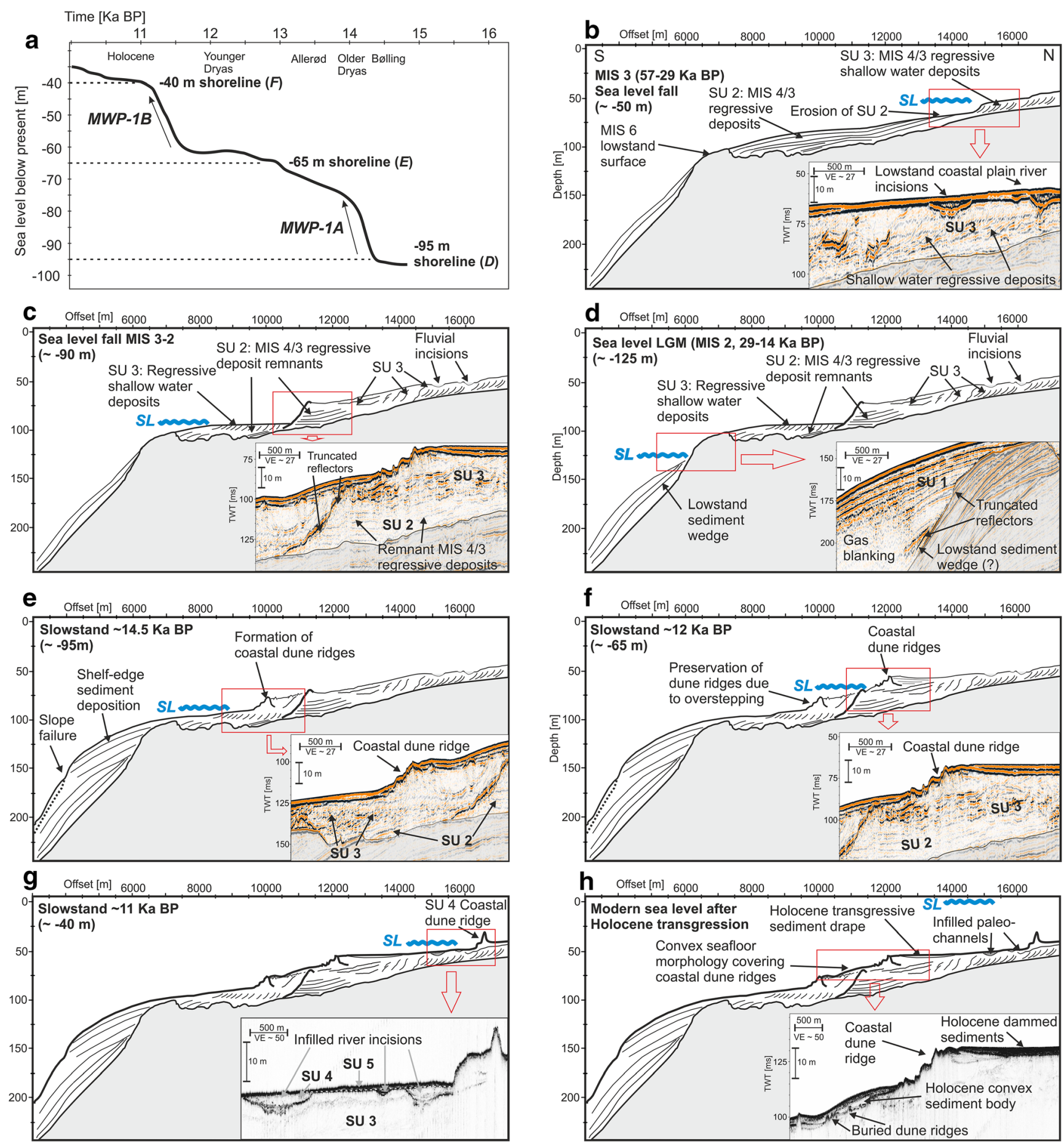
4 Fig. 7 Reconstruction of the geological development of profile GeoB08183 (Fig. 3) during the last sea-level cycle as an example for the southern Mozambique shelf. (A) Sealevel development during the post-glacial transgressions showing Melt Water Pulses (MWP) as periods of rapid sealevel rise with intermittent sealevel stillstands/slowstands. Modified after Salzmann et al. (2013) and references therein. (B) MIS 4/3 regressive shelf deposits (SU 2) overlie the prominent MIS 6 lowstand erosive surface. These sediments are eroded during the sea-level fall during MIS 3 and regressive shallow water deposits are formed (SU 3). (C) During rapid sea-level fall in MIS 3/2 SU 2, sediments are truncated and partly preserved on the middle shelf. (D) Complete subaerial exposure of the shelf area during LGM sea-level lowstand ( $-125 \mathrm{~m})$. The LGM shoreline is indicated by truncated reflectors and a possible lowstand sediment wedge. (E) During sealevel rise shelf edge sediments are deposited by the Limpopo River. As sea-level stabilized at $\sim 95 \mathrm{~m}$, a coastal dune ridge (SU 4) was formed along the shoreline. (F) After rapid sea-level rise (MWP 1A), sea level stabilized at $\sim 65 \mathrm{~m}$, leading to the development of a second coastal dune ridge (SU 4). However, variability of dune ridges along the shelf is significant (Fig. 2), indicating the large impact of local topography on shoreline development. (G) Further rapid sealevel rise (MWP-1B) to $\sim 40$ m oversteps existing dune ridges on the middle shelf. Fluvial channels are infilled during transgression and a new dune ridge at $\sim 40 \mathrm{~m}$ develops. (H) After the transgression, the submerged dunes are covered by a Holocene sediment drape (SU 5) that shows damming behind dune ridges on the inner shelf

However, preserved SU 2 deposits are not present towards the east of the study area (Fig. 5) which suggests that this configuration may be locally caused by e.g. pre-existing seafloor morphology. Such morphology could be caused by additional sediment input from the Limpopo River leading to thick SU 2 deposits in the east, contrasting with originally relatively thin SU 2 deposits in the west. Several incisions were observed in the upper boundary of SU 3 on the middle and inner shelf which may correspond to fluvial valleys (Figs. 3A, D and 6). The incisions show widths of 100-1000 $\mathrm{m}$ and depths of up to $20 \mathrm{~m}$ (Figs. 3A, D and 6). The modern Limpopo shows a width of around $100 \mathrm{~m}$ close to its termination with a flood plain of several kilometers width including numerous meander loops (Spaliviero et al. 2014; Sitoe et al. 2015). Thus, these fluvial channels probably represent the course of the Limpopo River during shelf exposure (Figs. 3A, D and 6). This suggests an eastward course of the paleo-Limpopo from the modern Limpopo River mouth on the exposed shelf during sealevel lowstand. The further paleo-Limpopo course on the shelf including the termination at the shelf break was not imaged but is expected towards the east of the study area (Fig. 2A).

The LGM maximum sealevel lowstand in the study area was at $-125 \mathrm{~m}$ based on truncated reflectors and a potential small lowstand sediment wedge at the shelf break (Figs. 3A and 7D). This observation agrees with the $-125 \mathrm{~m}$ LGM sea level established in the region (Ramsay and Cooper 2002; Green and Uken 2005). During sealevel lowstand, the complete shelf was exposed and the coastline was situated just beyond the shelf break at the time (Fig. 7D), resulting in Limpopo River sediment being exported directly to the slope.
In other areas, coastal dune ridges were interpreted to have formed during the MIS 3 sealevel fall, e.g., on the Western Australian shelf (Brooke et al. 2014), which contrasts with our observations. There are no indications for such coastal dune ridges forming during sealevel fall on the southern Mozambique shelf. The only indications for individual sealevel positions during the overall sealevel fall of MIS 4-2 are the truncations of SU 2 on the middle shelf (Fig. 3). Furthermore, examples of preserved dunes on the exposed shelf are known from the Western Australian shelf (Nichol and Brooke 2011), but could not be observed here, either due to limited dune activity in the vegetated coastal hinterland or due to their erosion during the following transgression.

\section{Post-LGM sealevel rise}

The transgression during the deglaciation occurred in several episodes of sealevel rise at different rates. It includes so-called slowstands, times of very slow sealevel rise, and times of rapid sealevel rise, associated to melt water pulses (MWPs) (Fig. 7A; Camoin et al. 2004; Liu and Milliman 2004; Bard et al. 2010; Zecchin et al. 2011). The deposits of SU 4, which overlie shallow water regressive deposits (SU 3), are interpreted to form during transgression in a high-energy regime in relatively shallow water similar to units mapped further south on the shelf (Green 2009; Green and Luke Garlick 2011). The transparent character of SU 4 without apparent internal structure and a high amplitude upper boundary is interpreted to correspond to reworked sands. Areas with thin SU 4 deposits (Figs. 3B, D and 4B) may represent remnants of such reworked sands during ongoing transgression. Thicker parts of SU 4 are part of the submerged ridges that are related to paleocoastlines. The submerged ridges are interpreted as lithified submerged coastal dunes, probably containing beachrock components, which formed directly at the coastline when sea level remained stable for a certain period of time (Mauz et al. 2015; Green et al. 2013). Similar examples have been attributed to various sealevel positions on the shelf along the SE African margin (Flemming 1981; Ramsay 1994; Green 2009; Green et al. 2014, 2018; Pretorius et al. 2016).

The deepest discernible sealevel indication within SU 4 deposits can be observed at about $-95 \mathrm{~m}$ (Figs. 3, 4, and 5), which corresponds to a $-95 \mathrm{~m}$ coastline on the shelf (Fig. 2). This shoreline correlates with high amplitude truncation surfaces of the upper boundary of SU 3 (Fig. 3B) and seafloor topography of SU 4 deposits (Fig. 4B) in front of a set of dune ridges (Figs. 3 and 4). The observed distance to the first major dune ridge of several hundred meters (Figs. 3 and 4) may correspond to an extended beach area or foredune plain in front of a major coastal dune belt (Hesp and Walker 2013). Such a foredune plain may have formed as a prograding beach system as sea level remained stable at $-95 \mathrm{~m}$ for several decades to centuries (Fig. 7A and E). Contrastingly, no 
extended beach area or foredune plain is observed at the $95 \mathrm{~m}$ coastline on the western profile where a major dune ridge is present directly at the coastline (Fig. 5E). This may be due to the steep shelf relief in close proximity to the shelf break (Fig. 5) compared to the area further east (Figs. 3 and 4). This setting facilitated sediment export from the coastline directly beyond the shelf break. This paleo-shoreline, including the associated dune ridges, is interpreted to have formed during a slowstand in sealevel rise (Fig. 7A) at $\sim 95 \mathrm{~m}$ that corresponds to the Bølling Interstadial ( $14.5 \mathrm{ka})$ (Salzmann et al. 2013). This slowstand would have allowed the coastline to form considerable topography in the form of aeolianites and early-cementation beachrocks, as suggested for other locations along the SE African margin (Salzmann et al. 2013). Sealevel rise to this position from -125 to $-95 \mathrm{~m}$ appears to have occurred rapidly as no indications for intermittent coastline stability can be observed (Figs. 3, 4, and 5).

Continued transgression often erodes coastal dune ridges if sealevel rise occurs gradually and allows for sufficient time for wave ravinement and sediment reworking (Green et al. 2018; Pretorius et al. 2018). Contrastingly, shoreline features may be preserved during rapid sealevel rise and associated overstepping, due to the reduced time for wave ravinement (Gardner et al. 2005, 2007; Storms et al. 2008; Green et al. 2013). This pattern of overstepping has been widely observed along the SE African coast and seems to be a prevailing mechanism for the preservation of such coastal barrier systems (Salzmann et al. 2013; Green et al. 2013, 2014; Cooper et al. 2016). Additionally, early cementation of coastal dunes also increases their potential resilience to erosion (Gardner et al. 2005, 2007; Salzmann et al. 2013; Green et al. 2014, 2018). Cementation of calcareous sands in coastal dunes has even been associated to allow dunes formed during the regression or sealevel lowstand to withstand the following transgression (Nichol and Brooke 2011; Brooke et al. 2014). A rapid sealevel rise from -96 to $-75 \mathrm{~m}$ during the transgression is associated to a prominent melt water pulse (MWP-1A) between 14.3 and 14.0 ka BP (Fig. 7A) (Fairbanks 1989; Bard et al. 1990). This range of rapid sealevel rise coincides with the depth range of preserved coastal dune ridges in our data (Fig. 7E and F) and has been associated with the overstepping of similar coastal barrier complexes further south (Salzmann et al. 2013; Green et al. 2014; Cooper et al. 2016).

A second consistent line of shoreline indications at $\sim-65 \mathrm{~m}$ is visible as a second line of submerged ridges on the Limpopo Shelf (Figs. 2, 3, 4, and 5). In the eastern part of the study area, this coastline consists of a set of submerged dune ridges, very similar in appearance to the deeper one at $-95 \mathrm{~m}$ (Figs. 3 and 4). In the western part (Fig. 5), the $-65 \mathrm{~m}$ shoreline corresponds to a prominent set of ridges, although the higher number of individual ridges suggests a more complex coastline development there. This difference indicates a distinct variation in shoreline evolution within the study area (see "Lateral variability of dune ridge occurrence on the Limpopo Shelf' section). The position of the shoreline at $-65 \mathrm{~m}$ agrees well with the sealevel slowstand of the Younger Dryas (12.7-11.6 ka, Fig. 7A) (Camoin et al. 2004). Similar to the submerged ridges at $-95 \mathrm{~m}$, a stable sea level or a very slow sealevel rise would have allowed the formation of a coastal dune complex (Fig. 7F). Parts of SU 4 showing medium amplitude parallel and subparallel reflectors on the middle shelf (Figs. 4D and 5D) may represent lagoonal deposits that formed during the sealevel slowstand of the Younger Dryas (Fig. 7A). Protected lagoons and tidal flats may have formed behind barrier islands resulting from coastal dune complexes during slow sealevel rise (Green et al. 2013). This setting is similar to currently present swamp areas behind the coastal dune systems onshore where rivers flow through low-lying areas between dune ridges (Fig. 1; Tinley 1985; Hughes and Hughes 1992; Botha et al. 2003). Correspondingly, channel incisions can be observed behind submerged dune ridges offshore representing such coast-parallel river courses (Fig. 5C). The preservation of this second set of submerged coastal dune ridges at $-65 \mathrm{~m}$ is probably associated to overstepping during a second phase of rapid sealevel rise, i.e., MWP-1B (11.511.2 ka BP) when sea level rose from -58 to $-45 \mathrm{~m}$ (Fig. 7A, Liu and Milliman 2004).

After the rapid sealevel rise of MWP-1B, another period of sealevel slowstand occurred at $\sim 11 \mathrm{ka} \mathrm{BP}$ (Fig. 7A) and probably led to the formation of the shallowest set of shoreline indicators on the Limpopo Shelf at $\sim 40 \mathrm{~m}$ (Fig. 2, 3, 4, and 5). The rise in sea level during MWP-1B apparently led to varying shoreline development in relatively close proximity on the shelf with three intermediate dune ridges in the east (Fig. 5) and two ridges in the center (Fig. 4), contrasting with a lack of intermediate shoreline indicators in the west (Figs. 3 and $7 \mathrm{G})$.

The subsequent sealevel rise to modern highstand conditions led to the complete drowning of the shelf area. Highstand sediments consist of SU 5 deposits, a Holocene drape (e.g., Lobo et al. 2004; Cawthra et al. 2012) that covers underlying units and infills topography that was present on the exposed shelf (Fig. 7H, see "Holocene sediment deposition on the Limpopo Shelf" section).

Simultaneously with the post-LGM sealevel rise, sedimentation continued at the shelf break, building up SU 1 deposits there, probably resulting from Limpopo River sediment export during the early transgression (Fig. 7E and F).

\section{Lateral variability of dune ridge occurrence on the Limpopo shelf}

The number, geometry, and extent of submerged dune ridges on the Limpopo Shelf is variable over short distances (Fig. 2). Similarly, the overall seafloor morphology varies along the shelf with an extended and low-relief outer shelf in the east 
compared to the western profiles (Fig. 2C). The numerous dune ridges in the west (Fig. 5) apparently coalesce eastwards to form the sets of ridges observed there (Figs. 2, 3, and 4). Individual dune ridges are thought to represent specific semistable sea levels, thus corresponding to the overall sealevel evolution (see "Post-LGM sealevel rise" section). However, the higher number of ridges compared to sealevel still-/ slowstands during the post-LGM transgression (see "PostLGM sealevel rise" section) suggests a more complex coastline development than is implied by sealevel evolution alone.

A significant factor for shoreline development during transgression is the pre-existing topography of the shelf as it governs accommodation space and rate of shoreline translation (Green et al. 2018). The geometry of the exposed shelf before the onset of transgression is formed by the upper boundary of SU 3 and the erosive truncation of SU 2 (Fig. 7D). SU 3 closely follows the topography of the underlying MIS 6 unconformity, which shows considerable variations along the shelf, especially on the outer shelf (Figs. 3, 4, and 5). In the eastern profiles (Figs. 3 and 4), a low-relief MIS 6 surface is due to increased thicknesses of underlying pre-MIS 6 sediments. These pre-MIS 6 shelf-edge sediment accumulations show large changes of volume along the shelf, leading to a lower relief outer shelf on the east and a steeper outer shelf in the west. Such volumes of sediment probably originate from the Limpopo River which has flowed eastward on the exposed shelf during the LGM, and possibly also during earlier sealevel lowstands (Fig. 2A, "Pre-LGM sealevel fall" section). Additionally, the preserved regressive SU 2 deposits on the middle shelf (Figs. 3 and 4, "Pre-LGM sealevel fall" section) form a step in shelf topography before the deglacial transgression (Fig. 7D). Due to this topographic configuration of the shelf prior to the onset of sealevel rise relatively long time intervals of the sealevel rise occurred at steep sections of the shelf, e.g., the truncated SU 2 sediments, with a relatively stable coastline at this location. This increased geographical stability of the coastline over time allowed the formation of large coastal dune complexes in the east (Figs. 3 and 4), contrasting with relatively equidistant individual coastal dune ridges in the west (Fig. 5). A similar effect may be observed in onshore dune ridge geometry in the area east of the Inharrime River (Fig. 1A) where dune ridges merge as they and the coastline change their strike from SW-NE to SSW-NNE. This may be due to a more stable eastern coastline compared to the southern coast, probably over various sealevel cycles, resulting in the lateral variability in the number and morphology of coastal dune ridges.

In the western profile (Fig. 5), the MIS 6 unconformity shows a steeper topography on the outer shelf due to the lack of pre-MIS 6 shelf-edge sediment accumulations that are present further east. Furthermore, the western profile does not show remnant SU 2 sediments preserved on the shelf (Fig. 5). Therefore, the steeper outer shelf and the relatively smooth topography of the SU 3 regressive deposits led to relatively equally distributed dune ridges across the shelf, including ridges close to the shelf break (Figs. 2 and 5). The numerous ridges are located close to each other and often show overlapping depth ranges, i.e. the sea level expected for a landward ridge also intersects with a seaward ridge (Fig. 5C). Thus, it appears likely that this area of the shelf showed numerous lagoon settings during transgression with barrier islands formed by previously active dune ridges, which resisted the erosion during continued transgression. Numerous ridges in the western part of the study area occur within $\sim 10 \mathrm{~m}$ above the $-65 \mathrm{~m}$ shoreline (Figs. 4 and 5) and may represent different stages of sealevel evolution during the extended sealevel slowstand of the Younger Dryas (Fig. 7A). Commonly, the preservation of such ridges has been attributed mainly to their overstepping by phases of rapid sealevel rise (Salzmann et al. 2013; Green et al. 2014; Pretorius et al. 2016). However, the data on the Limpopo Shelf show that these ridges must be resistant to wave erosion as consecutive landward dune ridges are formed even after only minor sea level rises. The causes for this high resistance to erosion even under continued wave action are unclear but may be due to increased early cementation (Green et al. 2018).

\section{Holocene sediment deposition on the Limpopo shelf}

The thickness of Holocene sediments (SU 5) varies considerably on the Limpopo Shelf. Maximum thickness $(\sim 10 \mathrm{~m})$ occurs where sediments, most probably riverine input from the Limpopo River as the major sediment source, is accumulated landward of submerged coastal dune ridges (Fig. 4D). Amplitude blanking in sediment echosounder data in this unit is probably due to biogenic methane forming in organic rich fluvial sediments (Fig. 5D). Holocene deposits are much thinner towards the outer shelf (Figs. 3B, 4B, and 5B). The damming effect results from a capture of Limpopo River sediments on the inner shelf and a limited export towards the shelf break, similar to examples from the South African shelf (e.g., Flemming 1981). Additionally, the convex shape of Holocene sediment bodies on the middle shelf (Figs. 3C and 4C) as well as moats along the dune ridges (Fig. 4D) suggest the shaping of seafloor sediments by along-shelf bottom currents (Cattaneo et al. 2003; Liu et al. 2007). This observation together with the absence of large Holocene sediment accumulations on the outer shelf indicates a possible current-driven along-shelf transport of Limpopo River sediments. This modern lack of sediment accumulations on the outer shelf contrasts with the thick SU 1 sediment accumulations at the shelf edge that formed as the Limpopo River could deliver sediment to the outer shelf during periods of lower sea level. This inferred sediment transport agrees with the prevailing northeastward current direction along the coast associated to the Delagoa Bight Lee Eddy (Fig. 1A) (Lutjeharms and Da Silva 1988; Lamont et al. 2010). An efficient eastward transport of Limpopo sediment has also been suggested based on sediment sampling in the area. Provenance analyses of 
seafloor sediment samples showed a predominantly eastward transport of suspended Limpopo sediments towards the eastern Inharrime Terrace (Schüürman et al. 2019).

\section{Conclusion}

The topography and geologic appearance of the Limpopo Shelf has been shown to be the result of sealevel development and local variations in pre-existing topography. The dynamics of sealevel rise during the post-LGM transgression shape the shelf deposits by leading to the formation of various paleo-shorelines during periods of relatively stable sea level. Prominent paleoshorelines have been identified at $-95,-60$, and $-40 \mathrm{~m}$ water depth, corresponding to periods of sealevel slow-/stillstand during the overall transgression. The preservation of these shorelines and their associated coastal dune ridges have usually been attributed to their overstepping during times of rapid sealevel rise, i.e., melt water pulses. However, the number and position of individual ridges on the Limpopo Shelf suggests a high resistance of these ridges to erosion while landward coastal dune systems are active and older dune systems exist as offshore barriers. Also, a high variability in number and appearance of ridges along the shelf has been documented. This is attributed to local variations in the pre-existing topography during transgression, which is shaped by outer shelf sediment accumulations and remnant MIS 4/3 regressive sediments on the middle shelf. These findings highlight the importance of the local geological setting such as the position of fluvial sediment sources (Limpopo River) on the shelf, in defining shoreline development during transgression. During times of highstand sea level, the prominent submerged dune ridges form barriers for Holocene sediment export from the river mouth to the shelf edge. Sediment is dammed on the inner shelf and along-shelf current-induced sediment transport is facilitated by the coast-parallel ridges, stressing the impact of shelf development on sediment dynamics on modern shelves.

Acknowledgments $R / V$ Meteor Cruise M75/3 was funded by the Deutsche Forschungsgemeinschaft (DFG) and was associated to the SAFARI IODP proposal. We would like to thank the captain, crew and scientific party of $R / V$ Meteor Cruise M75/3 for their excellent work and support of the scientific research. We also thank Schlumberger and IHS for providing academic licenses for their software Vista 2D/3D seismic processing and The Kingdom Software, respectively. We would like to thank Prof. Ralph Schneider for fruitful discussions and general support of this study.

Funding Information Open Access funding provided by Projekt DEAL.

Data availability The used data may be accessed by contacting the corresponding author or through the PANGAEA website.

Open Access This article is licensed under a Creative Commons Attribution 4.0 International License, which permits use, sharing, adaptation, distribution and reproduction in any medium or format, as long as you give appropriate credit to the original author(s) and the source, provide a link to the Creative Commons licence, and indicate if changes were made. The images or other third party material in this article are included in the article's Creative Commons licence, unless indicated otherwise in a credit line to the material. If material is not included in the article's Creative Commons licence and your intended use is not permitted by statutory regulation or exceeds the permitted use, you will need to obtain permission directly from the copyright holder. To view a copy of this licence, visit http://creativecommons.org/licenses/by/4.0/.

\section{References}

Armitage SJ, Botha GA, Duller GAT, Wintle AG, Rebêlo LP, Momade FJ (2006) The formation and evolution of the barrier islands of Inhaca and Bazaruto, Mozambique. Geomorphology 82:295-308

Bard E, Hamelin B, Fairbanks RG (1990) U-Th ages obtained by mass spectrometry in corals from Barbados: sea level during the past 130 , 000 years. Nature $346: 456$

Bard E, Hamelin B, Delanghe-Sabatier D (2010) Deglacial meltwater pulse $1 \mathrm{~B}$ and Younger Dryas Sea levels revisited with boreholes at Tahiti. Science 327:1235-1237

Botha GA, Bristow CS, Porat N, Duller G, Armitage SJ, Roberts HM, Clarke BM, Kota MW, Schoeman P (2003) Evidence for dune reactivation from GPR profiles on the Maputaland coastal plain, South Africa. Geol Soc Lond, Spec Publ 211:29-46

Brooke BP, Olley JM, Pietsch T, Playford PE, Haines PW, MurrayWallace CV, Woodroffe CD (2014) Chronology of quaternary coastal aeolianite deposition and the drowned shorelines of southwestern Western Australia - a reappraisal. Quat Sci Rev 93:106-124

Camoin GF, Montaggioni LF, Braithwaite CJR (2004) Late glacial to post glacial sea levels in the Western Indian Ocean. Mar Geol 206:119-146

Cattaneo A, Correggiari A, Langone L, Trincardi F (2003) The lateHolocene Gargano subaqueous delta, Adriatic shelf: sediment pathways and supply fluctuations. Mar Geol 193(1-2):61-91

Cawthra HC, Neumann FH, Uken R, Smith AM, Guastella LA, Yates A (2012) Sedimentation on the narrow ( $8 \mathrm{~km}$ wide), oceanic currentinfluenced continental shelf off Durban, Kwazulu-Natal, South Africa. Mar Geol 323-325:107-122

Cooper JAG, Pilkey OH (2002) The barrier islands of Southern Mozambique. J Coast Res Spec Issue 36:164-172

Cooper JAG, Pilkey OH (2004) Sea-level rise and shoreline retreat: time to abandon the Bruun rule. Glob Planet Chang 43:157-171

Cooper JAG, Green AN, Meireles RP, Klein AHF, Souza J, Toldo EE (2016) Sandy barrier overstepping and preservation linked to rapid sea level rise and geological setting. Mar Geol 382:80-91

Darmadi Y, Willis BJ, Dorobek SL (2007) Three-dimensional seismic architecture of fluvial sequences on the low-gradient Sunda Shelf, Offshore Indonesia. J Sediment Res 77:225-238

Fairbanks RG (1989) A 17,000-year glacio-eustatic sea level record: influence of glacial melting rates on the Younger Dryas event and deep-ocean circulation. Nature 342:637

Flemming BW (1980) Sand transport and bedform patterns on the continental shelf between Durban and Port Elizabeth (southeast African continental margin). Sediment Geol 26:179-205

Flemming BW (1981) Factors controlling shelf sediment dispersal along the southeast African continental margin. Mar Geol 42:259-277

Gardner JV, Dartnell P, Mayer LA, Hughes Clarke JE, Calder BR, Duffy G (2005) Shelf-edge deltas and drowned barrier-island complexes on the Northwest Florida outer continental shelf. Geomorphology 64:133-166

Gardner JV, Calder BR, Hughes Clarke JE, Mayer LA, Elston G, Rzhanov Y (2007) Drowned shelf-edge deltas, barrier islands and related features along the outer continental shelf north of the head of De Soto canyon, NE Gulf of Mexico. Geomorphology 89:370-390 
Green AN (2009) Palaeo-drainage, incised valley fills and transgressive systems tract sedimentation of the northern KwaZulu-Natal continental shelf, South Africa, SW Indian Ocean. Mar Geol 263:46-63

Green A, Luke Garlick G (2011) A sequence stratigraphic framework for a narrow, current-swept continental shelf: the Durban Bight, central KwaZulu-Natal, South Africa. J Afr Earth Sci 60:303-314

Green AN, Uken R (2005) First observations of sea-level indicators related to glacial maxima at Sodwana Bay, northern KwaZulu-Natal. S Afr J Sci 101:236-238

Green AN, Ovechkina M, Uken R (2008) Nannofossil age constraints for the northern KwaZulu-Natal shelf-edge wedge: implications for continental margin dynamics, South Africa, SW Indian Ocean. Cont Shelf Res 28:2442-2449

Green AN, Cooper JAG, Leuci R, Thackeray Z (2013) Formation and preservation of an overstepped segmented lagoon complex on a high-energy continental shelf. Sedimentology 60:1755-1768

Green AN, Cooper JAG, Salzmann L (2014) Geomorphic and stratigraphic signals of postglacial meltwater pulses on continental shelves. Geology 42:151-154

Green AN, Cooper JAG, Wiles EA, De Lecea AM (2015) Seismic architecture, stratigraphy and evolution of a subtropical marine embayment: Maputo Bay, Mozambique. Mar Geol 369:300-309

Green AN, Cooper JAG, Salzmann L (2018) The role of shelf morphology and antecedent setting in the preservation of palaeo-shoreline (beachrock and aeolianite) sequences: the SE African shelf. GeoMar Lett 38:5-18

Hesp PA, Walker IJ (2013) 11.17 Coastal Dunes. In: Shroder JF (ed) Treatise on geomorphology. Academic Press, San Diego, pp 328-355

Hübscher C, Spiess V (2005) Forced regression systems tracts on the Bengal shelf. Mar Geol 219:207-218

Hughes RH, Hughes S (1992) A directory of African wetlands. IUCN, UNEP, WCMC, Gland, Cambridge, Nairobi, Cambridge, p xxxiv + 820

Kelley JT, Belknap DF, Claesson S (2010) Drowned coastal deposits with associated archaeological remains from a sea-level "slowstand": Northwestern Gulf of Maine, USA. Geology 38:695-698

Lamont T, Roberts MJ, Barlow RG, Morris T, van den Berg MA (2010) Circulation patterns in the Delagoa Bight, Mozambique, and the influence of deep ocean eddies. Afr J Mar Sci 32:553-562

Lisiecki LE, Raymo ME (2005) A Pliocene-Pleistocene stack of 57 globally distributed benthic d180 records. Paleoceanography 20: PA1003. https://doi.org/10.1029/2004PA001071

Liu JP, Milliman JD (2004) Reconsidering melt-water pulses 1A and 1B: global impacts of rapid sea-level rise. J Ocean Univ China 3:183-190

Liu JP, Xu KH, Li AEA, Milliman JD, Velozzi DM, Xiao SB, Yang ZS (2007) Flux and fate of Yangtze River sediment delivered to the East China Sea. Geomorphology 85(3-4):208-224

Lobo FJ, Sánchez R, González R, Dias JMA, Hernández-Molina FJ, Fernández-Salas LM, Díaz del Río V, Mendes I (2004) Contrasting styles of the Holocene highstand sedimentation and sediment dispersal systems in the northern shelf of the Gulf of Cadiz. Cont Shelf Res 24:461-482

Locker SD, Hine AC, Tedesco LP, Shinn EA (1996) Magnitude and timing of episodic sea-level rise during the last deglaciation. Geology 24:827-830

Lutjeharms JRE (2006) The Agulhas current, 1st edn. Springer, Berlin

Lutjeharms JRE, Da Silva AJ (1988) The Delagoa Bight eddy. Deep Sea research part a. Oceanogr Res Pap 35:619-634

Martin AK (1981) The influence of the Agulhas current on the physiographic development of the northernmost Natal Valley (S.W. Indian Ocean). Mar Geol 39:259-276

Mauz B, Vacchi M, Green A, Hoffmann G, Cooper A (2015) Beachrock: a tool for reconstructing relative sea level in the far-field. Mar Geol 362:1-16

Mellett CL, Hodgson DM, Lang A, Mauz B, Selby I, Plater AJ (2012) Preservation of a drowned gravel barrier complex: a landscape evolution study from the North-Eastern English Channel. Mar Geol 315-318:115-131
Milliman JD, Meade RH (1983) World-wide delivery of river sediment to the oceans. J Geol 91:1-21

Nichol SL, Brooke BP (2011) Shelf habitat distribution as a legacy of Late Quaternary marine transgressions: a case study from a tropical carbonate province. Cont Shelf Res 31:1845-1857

Nordfjord S, Goff JA, Austin JA Jr, Gulick SPS (2006) Seismic facies of incised-Valley Fills, New Jersey continental shelf: implications for erosion and preservation processes acting during Latest PleistoceneHolocene transgression. J Sediment Res 76:1284-1303

Novak B, Pedersen GK (2000) Sedimentology, seismic facies and stratigraphy of a Holocene spit-platform complex interpreted from high-resolution shallow seismics, Lysegrund, southern Kattegat, Denmark. Mar Geol 162:317-335

Porat N, Botha G (2008) The luminescence chronology of dune development on the Maputaland coastal plain, Southeast Africa. Quat Sci Rev 27:1024-1046

Pretorius L, Green AN, Cooper JAG (2016) Submerged shoreline preservation and ravinement during rapid postglacial sea-level rise and subsequent "slowstand". GSA Bull 128:1059-1069

Pretorius L, Green AN, Cooper JAG (2018) Submerged beachrock preservation in the context of wave ravinement. Geo-Mar Lett 38:19-32

Preu B, Spieß V, Schwenk T, Schneider R (2011) Evidence for currentcontrolled sedimentation along the southern Mozambique continental margin since Early Miocene times. Geo-Mar Lett 31:427-435

Ramsay PJ (1994) Marine geology of the Sodwana Bay shelf, Southeast Africa. Mar Geol 120:225-247

Ramsay PJ, Cooper JAG (2002) Late quaternary sea-level change in South Africa. Quat Res 57:82-90

Saetre R, Da Silva AJ (1984) The circulation of the Mozambique channel. Deep sea research part A. Oceanogr Res Pap 31:485-508

Salzmann L, Green A, Cooper JAG (2013) Submerged barrier shoreline sequences on a high energy, steep and narrow shelf. Mar Geol 346:366-374

Schüürman J, Hahn A, Zabel M (2019) In search of sediment deposits from the Limpopo (Delagoa Bight, southern Africa): deciphering the catchment provenance of coastal sediments. Sediment Geol 380:94-104

Sitoe SR, Risberg J, Norström E, Snowball I, Holmgren K, Achimo M, Mugabe J (2015) Paleo-environment and flooding of the Limpopo River-plain, Mozambique, between c. AD 1200-2000. CATENA 126:105-116

Spaliviero M, De Dapper M, Maló S (2014) Flood analysis of the Limpopo River basin through past evolution reconstruction and a geomorphological approach. Nat Hazards Earth Syst Sci 14:2027-2039

Storms JEA, Weltje GJ, Terra GJ, Cattaneo A, Trincardi F (2008) Coastal dynamics under conditions of rapid sea-level rise: Late Pleistocene to Early Holocene evolution of barrier-lagoon systems on the northern Adriatic shelf (Italy). Quat Sci Rev 27:1107-1123

Sudan P, Whitmore G, Uken R, Woodbourn S (2004) Quaternary evolution of the coastal dunes between Lake Hlabane and cape St Lucia, KwaZulu-Natal. S Afr J Geol 107:355-376

Tinley KL (1985) Coastal dunes of South Africa. In: South African National Scientific Programmes Report 109, 304. Committee for Nature Conservation Research, Pretoria

Waelbroeck C, Labeyrie L, Michel E, Duplessy JC, McManus JF, Lambeck K, Balbon E, Labracherie M (2002) Sea-level and deep water temperature changes derived from benthic foraminifera isotopic records. Quat Sci Rev 21:295-305

Walsh JP, Nittrouer CA (2009) Understanding fine-grained river-sediment dispersal on continental margins. Mar Geol 263:34-45

Zecchin M, Ceramicola S, Gordini E, Deponte M, Critelli S (2011) Cliff overstep model and variability in the geometry of transgressive erosional surfaces in high-gradient shelves: the case of the Ionian Calabrian margin (southern Italy). Mar Geol 281:43-58

Publisher's note Springer Nature remains neutral with regard to jurisdictional claims in published maps and institutional affiliations. 